\title{
Implementation of School Culture Management in State Elementary School in the District of Aur Birugo Tigobaleh
}

\author{
Yuhelmi ${ }^{1, a^{*}}$, Ratna Sari Dewi Pohan ${ }^{1, b}$, and Mezia Kemala Sari ${ }^{1, c}$ \\ 1Department of English Education, Faculty of Teacher Training and Education, Muhammadiyah University of West Sumatera, Indonesia \\ a yuhelmi@umsb.ac.id; b ratnasaridewipohan@umsb.ac.id; c meziakemalasari@umsb.ac.id \\ ${ }^{*}$ Corresponding Author \\ Whatsapp number: [+6282174414411]
}

How to Cite : Yuhelmi, Y., Pohan, R., S., D., Sari, M., K. (2020). Implementation of School Culture Management in State Elementary School in the District of Aur Birugo Tigobaleh. International Journal for Educational and Vocational Studies, 2 (1), 37-40. DOI: https://doi.org/10.29103/ijevs.v2i1.1926

\section{ARTICLE HISTORY}

Received:12 November 2019

Revised: 27 December 2019

Accepted: 26 January 2020

\section{KEYWORDS}

School Culture Management; State Elementary School; Aur Birugo Tigobaleh;

\section{ABSTRACT}

The formation development and maintenance of school cultural values is very important in order to create honesty, mutual trust, discipline, neat, clean, beautiful and create a harmonious atmosphere so that the formation of student character is good. This study aims to describe the school's cultural planning and implementation. The subjects of this study were principals of primary schools, teachers and students in primary schools in the Aur Birugo Tigobaleh district. Data collection techniques in this study were carried out by means of observation, interviews and documentation. Data analysis techniques use techniques developed by Miles and Huberman (1996). The findings of this study include: (1) school cultural planning is not planned according to MoNE standards; (2) the implementation of school culture is implemented by every school member but it does not yet refer to the correct guidelines. For this reason, it is recommended that schools make plans and implement correctly according to applicable guidelines.

This is an open access article under the CC-BY-SA license.

\section{INTRODUCTION}

Management of culture and the school environment is one of the government's efforts to develop positive character of students. The management of culture and the school environment is carried out so that the school environment becomes a conducive place for seeding and developing the positive character of students. In addition, the management of culture and school environment aims to create the school's physical environment and the school's psychological-socio-cultural environment that is conducive to seeding and developing the positive character of students. For the development of school culture four stages are required, namely program planning, program socialization, program implementation, and program evaluation.

Based on observations in public elementary schools in the Aur Birugo District, Tigo Baleh, not all schools understand the importance of school culture. This can be seen from the fact that not all schools have development programs. It does not appear in the school culture development program document, so cases of habits that occur in schools such as the habits of students who arrive late and the parents of students who still do not care about the delays of their children. According to Masaong and Ansar (2012) this culture does not yet appear as symbols of belief in school. Finally, efforts made for a conducive school and cultural development program need to get support from all school members and high commitment.

\subsection{Understanding school culture}

According to Kotter \& Heskett in Prenhallindo (1992: 4) culture is the totality of behavior patterns, arts, beliefs, institutions, and all other products of human works and thought that characterize the conditions of a society or population that are transmitted together. Meanwhile, according to the Ministry of Education and Culture (1992: 149) culture (cultural) is defined as: mind; customs; something that has developed; something that becomes a habit that is difficult to change. In this case, tradition is defined as general ideas, attitudes and habits of the community that appear from the daily behavior that becomes the habits of groups in the community.

According to Riduwan (2012) school culture is a characteristic, character and the image of the school in the wider community. school culture as a distinctive characteristic of a school that can be defined through the values it adopts, the attitude it has, the habits that it displays, and the actions exhibited by all school personnel 
that form a special unity of the school system.

Koentjaraningrat classifies cultural aspects based on the dimensions of its form, namely: (1) Complex ideas or ideas such as thoughts, knowledge, values, beliefs, norms and attitudes. (2) Activist complexes such as communication patterns, dances, traditional ceremonies. (3) Materials resulting from objects such as art, equipment and so on. For culture to be a durable value, there must be a process of cultural internalization.

\subsection{The benefits of school culture}

Some of the benefits that can be drawn from efforts to develop a school culture include: (1) ensuring better quality work; (2) open all communication networks of all types and levels both vertical and horizontal communication; (3) more open and transparent; (4) increase solidarity and sense of kinship; (5) if it finds an error it can be fixed immediately; and (6) can adapt to the development of science and technology.

The Ministry of National Education (2007) states that efforts to develop school culture should refer to the following principles: (1) Focus on the vision, mission and goals of the school, (2) Creation of Formal and Informal Communications, (3) Innovative and willing to take risks, (4) has a clear strategy, (5) school performance oriented, (6) a clear evaluation system, (7) has a strong commitment, (8) commitment from the school leadership and citizens, (9) decisions based on consensus, (10) ) clear reward system, (11) Self-evaluation. In addition, efforts to develop school culture should also adhere to principles such as: teamwork, willingness, desire, joy, respect, honesty, discipline, empathy, and knowledge and courtesy.

\subsection{Characteristics of school culture}

According to Masaong and Ansar (2012) school culture has four characteristics, namely: (1) school culture is special because each school has a history, communication patterns, systems and procedures, vision and mission statements, (2) school culture is essentially stable and usually slow to change. School culture will change if there is a threat of crisis from other schools, (3) school culture usually has an implicit and not explicit history, (4) school culture appears as a representative symbol that underlies the beliefs and values of the school ".

According to Catab (2007) the characteristics of school culture can be seen according to the following hierarchy:

1. Basic Assumption, namely cultural concern at the deepest level, is the basic assumption of the unconscious and at the same time an accepted state of how school problems should be solved.

2. Values about what should be in the organization, what they need to pay attention to, and a source of inspiration for a person's strengths and impulses in taking attitudes, actions and decisions, as well as in moving and controlling one's behavior in an effort to form a school culture.

3. Norms are guides how members of the organization should behave in certain situations.

4. Artifacts are concrete manifestations such as systems, procedures, work systems, regulations, structures and physical aspects of the organization.

Based on the results of a survey in elementary schools in Aur Birugo Tigobaleh District researchers are interested in examining the management of school culture in Aur Birugo Tigobaleh Public Elementary Schools. Based on the background of the problem above, the general problem formulation in this study is "How is the management of school culture in the SD Negeri Aur Birugo Tigobaleh District?"

The purpose of this study is to describe the management of school culture in the Aur Birugo Tigobaleh District Public Elementary School, while specifically the objectives of this study are to: (1) Describe the school culture planning in the Aur Birugo Tigobaleh Public Elementary School ?; (2) Describe the implementation of school culture in the SD Negeri Aur Birugo Tigobaleh District?

\section{METHODS}

The design of this research is to use a qualitative descriptive method which aims to provide a detailed and thorough description of the reality and facts of the nature of this research. According to Sugiyono (2012: 35) Qualitative descriptive research is a method that aims to describe or describe the situation in the field systematically with the facts with the proper interpretation and interconnected data, and not only to search for absolute truth but in essence seek understanding of observation, then the situation in the field is evaluated. The informants of this study are the 16 principals and primary school teachers in Aur Birugo Subdistrict, Tigo Baleh. Data collection techniques in this study were carried out in three ways, namely: observation, interview and documentation. Data analysis techniques use techniques developed by Miles and Huberman (1996).

\section{RESULTS AND DISCUSSION}

\section{Results}

\subsection{School Culture Planning}

School culture as a formal educational institution, consist of educators and students. School cultural values need to be planned in order to create a good relationship between teachers and students and fellow students in the SD Negeri District in Aur Birugo Tigobaleh.

The tradition in schools is not planned by the principal but has been entrenched and has been running for a long time in the Public Elementary School in Aur Birugo District, Tigobaleh. The results of observations studied by researchers show that in public elementary schools in the region always apply traditions that can create student characters for example all students are obliged to dress for 
Muslims who are Muslim. In addition to all public elementary schools, they have also applied the principle of developing school culture, namely: always oriented towards achieving goals; develop a clear vision and its contents become the common property.

For school culture in Aur Birugo Tigobaleh Public Elementary School, according to interviews with school principals and teachers that this public elementary school has also implemented $4 \mathrm{~S}$ (Sapa, Smile, Salam and Polite) so that this school can shape the character of students in accordance with religion. In addition, in the Aur Birugo District Elementary School Tigobaleh implements 10 shame cultural disciplines that are installed on each school wall.

\subsection{Implementation of School Culture}

Values that underlie behavior need to be implemented properly. According to the results of interviews with principals and teachers have been well socialized and implemented. The socialization of school culture is carried out in the form of official meetings and displays which are attached to the school's cultural environment so that it can be read by all school residents in the SD Negeri environment in Aur Birugo District Tigobaleh.

Based on interviews with school principals and teachers and documentation studies, it was found that the implementation of school culture is grouped into two programs, namely a physical program covering the arrangement of the school environment that is capable of becoming an arena for cultural values, and an environmental development program covering a psychological, social atmosphere, harmonious and fun school culture.

In the tradition of school in addition to each coming and going home from school students kiss the teacher's hand (greetings) which can provide a good tradition, among others, the creation of conducive environmental conditions requiring certain prerequisites, which in particular must be managed by school management and other school stakeholders. Fellow students make friends with each other, exercise together with applicable regulations, mutually invite and invite each other, tell stories to one another, discipline one another so as not to offend his peers. In the school environment an individual is also confronted with a broader pattern of life orientation. Where these set of activities he did not meet in the family.

\section{Discussion}

\section{School culture planning}

School cultural values need to be planned in order to create a good relationship between teachers and students as well as fellow students in the SD Negeri environment in Aur Birugo Tigobaleh District. Some things that must be present in the creation of a conducive school environment are: sturdy and healthy school buildings, playing fields as a space to develop motor and psychomotor, shade trees for oxygen production and bring coolness, sanitation systems and water absorption wells need to be made so that a well-organized sanitation system accompanied by a lot of water catchment so that it does not cause flooding, providing a landfill to grow a clean culture, the environment around the school that supports the school.

The six things above are physical facilities that encourage the creation of a conducive school environment, but to get to a conducive condition moral and or ethical support is also needed. In school culture planning, it is usual for school principals and teachers to be able to set good examples that can be emulated by students.

In the learning process that occurs today we are often trapped in the view that what is meant by learning resources is limited to books, expert opinions, or laboratory results. This view is indeed not one hundred percent wrong but has ruled out the existence of an environment which is basically the source of all learning resources. Semiawan (1989: 96) argues that in fact we often forget the learning resources around us, both in the school environment and outside the school environment.

\section{Implementation of School Culture}

To find out the implementation of the school culture, the researchers observed the Aur Birugo Tigobaleh District Elementary School accompanied by the school principal and teachers. In this study students implement every school culture that has been planned by the school.

Development of Character Education through the Development of School Culture in Public Elementary Schools in the Aur Birugo Tigobaleh Sub-district region still does not fully refer to the principles of primary school culture development that is sustainable, integrated, consistent, implementative, and fun. In implementing the traditions that exist in the Public Elementary School in Aur Birugo District Tigobaleh, the school residents only apply the tradition that is usually done in the Public Elementary School by applying the rules given by the school. For example the tradition of wearing a veil for female students, the tradition of throwing trash in its place, the tradition of reading 15 minutes before the lesson begins. Every morning students, teachers and school principals are required to read books before teaching and learning activities begin. In addition, this school also applies the tradition of prayer when learning begins and after the teaching and learning process ends, other traditions have lines when they want to enter class.

Thus the efforts to develop school culture have not referred to the following principles: (1) focus on the vision, mission and goals of the school; (2) creation of formal and informal communication; (3) innovative and willing to take risks: (4) have a clear strategy; (5) performance oriented; (6) clear evaluation system; (7) has a strong commitment; (8) decisions based on consensus; (9) clear reward system; and (10) self-evaluation (MONE, 2007). For this reason, there needs to be implementation in habit oriented towards achieving goals; develop a clear vision and its contents 
become the common property. Develop good cooperation between educators in formal and informal interactions, so that vision and mission and indicators in the school are achieved.

\section{CONCLUSION}

From the results of data analysis and discussion it can be concluded that school culture management in public elementary schools in the Aur Birugo Tigobaleh Subdistrict is First, School culture planning which includes values adhered to school culture, traditions, habits, symbols practiced by principals, teachers and students are still not planned according to Ministry of National Education standards. Second, the implementation of school culture which includes values held by the school culture, traditions, habits, symbols practiced by school principals and teachers and students have been implemented by every school member but have not referred to the correct guidelines.

\section{Acknowledgements}

Based on the conclusions from the results of research conducted at the Public Elementary School in the Aur Birugo Tigobaleh District area, the researcher gave several suggestions, among others: it is hoped that the principal can create, plan, implement better values, habits, traditions and symbols in the school to be applied and implemented to all members of the school in order to shape the character of students in accordance with the implementation of school culture management.

\section{REFERENCES}

Arikunto, Suharsimi, (1997). Prosedur Penelitian Suatu pendekatan Praktik. Jakarta: Rineka Cipta

Chatab, Nevizond, (2007). Profil budaya organisasi. Bandung : Alfabeta.

Departemen Pendidikan Nasional, 2003. Undang Undang Republik Indonesia No 20 tahun 2003 tentang Sistim Pendidikan Nasional. Bandung: Citra Umbara

Kotter, J.P \& J.L. Heskett, (1992). Dampak Budaya Perusahaan Terhadap Kinerja. Terjemahan oleh Benyamin Molan, Jakarta : Prenhallindo.

Masaong, Abd Kadim \& Ansar. (2011). Manajemen Berbasis Sekolah (Teori, Model dan Implementasi. Gorontalo : Senta Media.

Riduwan. (2012). Metode dan Teknik Menyusun Proposal Penelitian. Bandung : Alfabeta. 